\title{
Every Thoughts on leadership: \\ Librarian \\ a Leader \\ An exchange
}

\author{
By Karyle Butcher, Joy Hughes, and Melvin R. George
}

\section{Library leadership succeeds with cooperation and support}

E d. note: In the July/August issue of CERL News, Patricia Breivik wrote an article entitled "Becoming Beyond-Library-Walls Librarians." Mel George, director of Oregon State University (OSU) Libraries, asked Karyle Butcher and Joy Hughes to read Breivik's article and respond to the questions he devised. He thought their perspective would be useful since they are both longtime advocates of librarians partnering across campus and across the state. Hughes has led the way for library involvement in linking with information providers throughout the state; Butcher is currently serving on a statewide committee to investigate site licensing for the state, and is actively involved in state and local politics.

George: You have read Patricia Breivik's introductory column dealing with her theme for the year, "Every Librarian a Leader." Do you think librarians have been very effective in revealing leadership skills on their own campuses? Why or why not?

Hughes: Breivik talks about librarians becoming "beyond-library-walls leaders." On some campuses the leadership issue is more one of removing the walls between the library and other information services professionals. When these walls are removed, librarians soon find themselves in positions of leadership. At OSU, for example, Karyle, an associate university librarian (AUL), is also head of consulting services for all of information services (IS). In that role she is leading librarians, but she is also leading professionals from the Media Services and Computer Services Departments. Her Consulting Services Unit is in charge of all training and instruction provided to the campus by IS and all front line and expert IS consultation with faculty, staff, and students. Charlene Grass, OSU's other AUL, is now the head of IS's project management group-and that's project management for network services, media services, and computer services, as well as the library.

Butcher: While I agree with Joy that there are some very exciting events happening within OSU Information Services in terms of leadership roles for librarians, I am not convinced that academic librarians in general see themselves as able to cross campus boundaries. I don't think the issue is ability; my personal experience and observations tell me that academic librarians can be quite effective in networking and developing partnerships with their colleagues across campus. The issue is that, unlike public librarians who have known for years that they must convince the public and their elected constituencies of the value of the public library, we in academia seem to believe that leadership is the job of our upper-level administrators.

Yet librarians have ample opportunity to interact with faculty through committee work, liaison work, research collaboration, and through their work at the public services desks. Information gleaned through these contacts can be used to increase faculty awareness of the library and also to bring back to the library issues and concerns of faculty. Frequently, oneon-one interactions between faculty and librarians take place in a vacuum with no feedback mechanism to those who might best respond to these concerns.

Karyle Butcher is an associate university librarian for research and public services at Oregon State University (OSU), e-mail: butcberk@ccmail.orst.edu. Joy Hughes is the associate provost for information services and a member of the library faculty at OSU, e-mail bughesj@ccmail.orst.edu. Melvin R. George is director of libraries at OSU, e-mail: georgem@ccmail.orst.edu 
Librarians are also playing more active roles in advocating for library services on the state and national levels. Oregon librarians, both public and academic, were instrumental in promoting and achieving the passage of a state initiative that funded five regional reference centers in the state. This came at a time when state funding was being reduced.

George: Do librarians have knowledge that might be appropriate to share with colleagues elsewhere on campus?

Butcher: Clearly we do. In the most obvious sense we have skills in accessing and retrieving information both in paper and electronic form, which puts us in the forefront on many campuses. On a more subtle level, but one which, in the long run, will prove imminently useful as we form partnerships across campus, is that as a profession we advocate for all. We push for increases in the materials budget not for any personal need to aggrandize the library but rather because we know that one of our primary missions is to serve campuswide information needs. If we combine this advocacy with an ongoing program of providing improved service to our users (a.k.a. customers), we can easily demonstrate to faculty and students centrality to the campus mission of teaching and research.

Moreover, the fact that the nature of our work is consultative adds to our special place on campus. Effective librarians excel in soliciting opinions and ideas from colleagues and users. As our organizations move towards a more team-based and interdisciplinary mode, the ability to listen, gather information, synthesize it, and present it to an audience will be invaluable.

Librarians are also in a position to advocate, along with classroom faculty, for an increase in the hiring and retention of people of color. Because we are working closely with the student population and are hiring from this same population, we are mindful of the changes taking place in the workforce and of the need to continue to diversify our staff.

George: Breivik challenges librarians to be academic leaders, particularly in teaching/learning aspects of campuses. Is that happening at OSU?

Hughes: Again, because of the removal of the walls between the library and other information service departments, librarians are now working with faculty on the development of multimedia instructional packages and on providing network access to course resources, whether these resources reside on campus or anywhere in the world. Without their involvement, the potential of multimedia to improve significantly the productivity of teaching and learning is far less likely to be realized. Librarians know about learning resources, know how to select them, access them, organize them, and make sure they are there next week when the next student or faculty member needs them.

George: In your role as associate provost for information services, Joy, do you see that technological development will thrust librarians into leadership roles in a way that is different from the past?

Hughes: I am very mindful of Johannah Sherrer's (library director at Lewis \& Clark College) concept of the "virtual collection." For years, I have been focused on the development of the national electronic library. I see now that for most librarians that is putting the emphasis in the wrong sphere of influence. Locally, librarians need to be meeting with academic departments to discuss their information needs and then assembling a virtual collection that will meet these needs. Once this collection is assembled, it, like any collection, will need to be maintained. (Who hasn't experienced the frustration of reaching out towards a URL that is no longer where it should be?) The leadership implications associated with the virtual collection concept are staggering-leadership with the faculty, students, catalogers, standardization groups, Webmasters throughout the world, etc. And, of course, librarians have to continue with their efforts to support the digitization of collections, providing leadership with respect to copyright, rights of individual users of information, software, information organization, etc.

George: What will the roles Joy describes require that is new of librarians?

Butcher: Frankly, unlike the vast body of current writing on organizational change in libraries, I do not see our role changing dramatically. We are in and have always been in the role of providing information to our users. What is very different is how this information is being packaged and presented and the skills we must have in order to access it. At OSU, technical services and public services librarians are working with others in information services to 
develop a campuswide Web, and to develop a teaching curricula that integrates classes formerly taught in the library, in computing services and in communications media. This has called for new skills in automation and increased skills in communication.

Hughes: I think Karyle and I have a different definition in mind when we use the word "role." I know the librarian's mission has always been to provide information to patrons, but I now see their roles as changing quite dramatically. This is illustrated by listing the characteristics possessed by a librarian/leader of twenty years ago as compared to those of a successful librarian/leader today. Managing change rather than maintaining stability is now required. Mastering a collection that grew slowly, year by year, is no longer a desired skill; participation in the creation of an electronic collection and being able to track networked and dynamic collections are the new skills. Participation in course development is another new skill asked of librarians. Working on teams that possess the authority to make significant decisions, both within and outside the library, is very different from providing input to a manager who, though participatory, still makes the final decisions.
George: You both paint different pictures with a similar theme: we need librarians to be leaders, and in very new ways. What rewards might be available to librarians who are leaders?

Butcher: The greatest reward will be personal and professional survival. If librarians are unable or unwilling to reach across the campus for partnerships with research and teaching faculty, we will have missed an opportunity to capitalize on our skills. Clearly, there is an ongoing need to increase salaries and to increase morale and job satisfaction by moving decision-making authority further down into the organization. All of us need to know that our work makes a difference to our users.

Hughes: An IS visioning group composed of important deans and key facuity, including the faculty senate president, set six IS goals. One of these says "the library is the hul of information services." That goal, and the explanatory material that accompanies it, provides evidence that campus decision-makers believe in the potential for library leadership in moving the university where it needs to be in the $21 \mathrm{st}$ century. The goal also indicates, though, that the library has not yet grasped the opportunity to lead the university. To the extent it does, the rewards will follow.

\section{PAPER COPIES from}

Micro-Opaque Cards

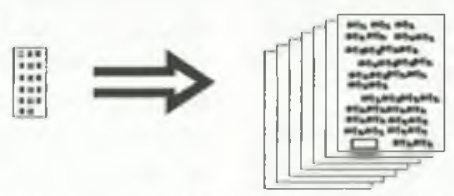

From our collection or yours-

This service is available for you, your faculty or your students. $\$ 5$ includes the first 10 pages, $25^{\complement}$ per page thereafter.

\section{Write or call for more information:}

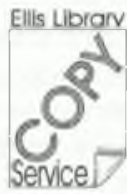

UNIVERSITY OF MISSOURI LIBRARIES

Kim Daugherty, 115 Ellis Library

Columbia, MO. 65201-5149

Phone 314-882-3398, Fax 314-884-5004 